\title{
Are the Talents Wisely Spent? The Case of Student Subsidies in Romanian Higher Education
}

\author{
Viorel Proteasa and Adrian Miroiu
}

Keywords Equity • Quality - Student subsidies · Distributive policies

\section{Introduction}

“...[A] man going on a journey [...] called his servants and entrusted to them his property. To one he gave five talents, to another two, to another one, to each according to his ability. Then he went away." (Matthew 25: 14-15 ${ }^{1}$ ). The Bible parable describes the different ways in which the servants used the money and it also gives an evaluation of the chosen investment strategies, from the perspective of the returning master.

International comparisons ${ }^{2}$ portray Romania as a country which needs to improve both quality and equity in higher education. At the same time, Romania is amongst the poorest countries in the European Union and invests low percentages of its national income in higher education. This naturally draws the attention to the morals of the parable of the talents: how efficiently is this money used? We are putting some old and some new analytical flesh on the equity versus quality dichotomy advanced in different reports (Vlăsceanu and Dima 2000, 9, Salmi and Hauptman 2006, 92), as we are trying to understand if Romania's "talents" are wisely spent.

\footnotetext{
1 English Standard Version, http://www.biblegateway.com/, accessed on the 18th of August, 2013. A "talent" was a monetary unit worth about 20 years' wages for a labourer.

${ }^{2}$ See for example http://ec.europa.eu/europe2020/europe-2020-in-your-country/romania/index_ en.htm.
}

V. Proteasa $(\bowtie)$

The Executive Agency for Higher Education, Research, Development and Innovation

Funding, Bucharest, Romania

e-mail: viorel.proteasa@gmail.com

A. Miroiu

National University of Political Studies and Public Administration (SNSPA),

Bucharest, Romania

e-mail: admiroiu@snspa.ro; ad_miroiu@yahoo.com

(C) The Author(s) 2015

A. Curaj et al. (eds.), Higher Education Reforms in Romania,

DOI 10.1007/978-3-319-08054-3_8 
This chapter is organised as follows. In the first section we discuss the criteria on which student subsidies are distributed and some of the mechanisms which may explain the perpetuation of past institutional arrangements. In the second section we focus on the characteristics of the recipients of the subsidies. Both sections include explanations of the concepts and methodology we used. In the concluding section we argue that the current context is more favourable than that of the late nineties for a more balanced relation between quality and equity in relation to student subsidies.

\section{The Distribution of Student Subsidies: Past and Present Perspectives}

A turning point for Romanian higher education was the change of political and economic regime in 1989-1990. In the early nineties, ${ }^{3}$ the Romanian universities ${ }^{4}$ acted in an institutional setting quite similar to that of the previous period. They continued being financed by the state and they were providing schooling free of charge on a much lower scale than demanded. As Miroiu and Vlăsceanu (2012) note, "[f]ive to fifteen candidates for one place represented the normal state in the case of medicine, law, humanities, business or economics programs", while higher education attainment level in the overall population continued to be amongst the lowest in Europe. Private higher education developed in parallel. Although they had no access to public funds, private universities proliferated: given the huge demand for higher education, much above the capacities of public universities, they started to enrol students who were willing to pay tuition fees themselves. The situation changed in 1998, when public universities started to enrol tuition paying students on top of the subsidised ones, hence extending their schooling capacities beyond the limit imposed by the public budget.

The same history, told in official statistics (INS 2013), can be summarised as follows: university enrolments ${ }^{5}$ started expanding in the early nineties, reached their historical maximum in 2007, and decreased substantially afterwards. Enrolments dropped in $2011 / 2012$ to $60 \%$ of the $2007 / 2008$ peak, with private universities ${ }^{6}$ suffering most: their enrolments dropped by $65 \%$ between 2008 and 2012 (CNFIS $2013,18)$. The evolution of participation rates within the cohort aged 19-24 follows a similar pattern.

\footnotetext{
3 This short overview is grounded in the historical account provided in Miroiu and Vlăsceanu (2012).

4 We will use "universities" in this article, as non-university tertiary education in Romania since 1990 influences only marginally the dynamics of higher education.

5 According to CNFIS $(2013,8)$, a statistical overview of physical students in Romania was never compiled; the available data count separate enrolments even when the same student takes more than one study programme.

6 The drop in enrolments was significantly determined by the evolution of "Spiru Haret" University. This university had negative press coverage on issuing of diplomas for its unaccredited
} 
In the nineties, the expansion of higher education was accompanied by an extension of the benefits to which students were entitled (Vlăsceanu and Dima 2000, 8-9). However, the overall public spending for higher education did not parallel the evolution of enrolments: Romanian universities have been "chronically under-financed" throughout this period. Between 2003 and 2011, the total funds allocated to cover the educational expenses of the subsidised students, the so-called "core funding", grew in real terms by only $5 \%$. Subsidies in public higher education take many forms: study grants ${ }^{7}$ or the so called "budgeted positions" within public universities, scholarships, accommodation facilities in student dormitories, student cafeterias, public transportation discounts, medical assistance, touristic packages, and discounts at public cultural institutions ${ }^{8}$ (e.g., museums). Some of the subsidies arrive in students' pockets, as cash (e.g., scholarships). Others take the form of direct payments for facilities students would have had to pay in the absence of the subsidy (e.g., part of the food costs in student cafeterias).

We can distinguish universal subsidies, i.e. subsidies to which all students are entitled, without additional criteria (e.g., free medical assistance), from specific subsidies that are distributed to a proportion of the students, based on some specific criteria (e.g., scholarships). These distribution criteria are extremely interesting for our discussion, as their configuration can denote the policy preference for equity or quality.

The distinction between these types of subsidies is not very sharp. For example, when demand exceeds provision, the appropriation of subsidies which are meant to be universal may be restricted, and distributive criteria are instituted. In-town public transportation discounts ${ }^{9}$ are in most cases available on a universal basis, but there are also cases when demand exceeded the funds allotted and the universities opted for some criteria of distribution. ${ }^{10}$

We restrict our discussion to study grants, scholarships and accommodation facilities in student dormitories. Cumulated, these forms of student support represent the bulk of the public funds for higher education. Their origins can be traced to the pre-war period (Berlescu 1960, Berciu-Drăghicescu şi Bozgan 2004, Rados 2010). These three types of subsidy are distributed based on criteria formalised in official regulations. The empirical part of this section is grounded on our own desk-

(Footnote 6 continued)

study programmes. During the same period, "Spiru Haret" University, although belatedly, imposed quality assurance measures.

7 The 2011 Education Law established that universities' teaching costs are to be financed through multiannual study grants. Currently this instrument is used only for the doctoral cycle. We use "study grants" to refer to the tuition the so-called "budgeted" students would pay in the absence of the subsidy.

${ }^{8}$ Students enrolled in private accredited institutions receive some subsidies, which include public transport discounts, medical assistance, touristic packages, and discounts at public culture institutions.

9 The central government pays for $50 \%$ discounts; when the local authorities contribute as well, the discount can reach $100 \%$. This is the case in Bucharest or Timisoara. There are also other arrangements, where students pay a certain per cent of the costs.

10 See for example Adevărul (2010) and Ziua de Cluj (2013). 
research of official regulations and it is complemented by descriptions provided by Salmi et al. (2014).

\subsection{Equity and Quality: Conceptual Clarifications}

Equity and quality are often part of the official rhetoric. They look like intuitive concepts, but their understanding is far from being generally acknowledged. Reading policy documents requires many times a certain dose of interpretation, as documents of this type generally do not include conceptual clarifications. The need for clarity may be more than an academic whim: as Marginson (2011) argues, different conceptual understandings of equity can generate different, sometimes conflicting evaluations of the corresponding higher education policies.

The law which currently regulates higher education in Romania includes equity and quality on the first places amongst its principles (Law Law 1/2011, Art 3, a) and b)). Equity is regarded as non-discriminatory access to education, where discrimination is used in its negative understanding. (Note that the law opens the possibility for affirmative action.) Quality is defined by reference to national and international standards and good practices. The law also refers to excellence and outstanding achievements which are to be stimulated (Law 1/2011, e.g. Art. 12, par. 3; Art. 223, par. 10).

We define a funding instrument as geared towards quality when merit-based logic is prevalent in the associated distributive pattern. While conceding that this assumption oversimplifies the causal chain, our approach is rooted in the popular wisdom according to which merit-based competition incentivises achievements, hence improves overall quality. Salmi and Hauptman $(2006,92)$ also argue that merit-based distribution of grants and scholarships improves quality. The Romanian law refers to this function of the scholarships (Law 1/2011, Art. 223(10)); we can also expect that such a view is shared by many Romanian policymakers.

We define a funding instrument as geared towards equity when its distributive pattern is prevalently sensitive to the individual characteristics which represent structural inequalities in Romanian higher education. ${ }^{11}$ The Romanian education law establishes a set of priorities in terms of equity ${ }^{12}$ : orphans, children from placement centres, Romanian ethnics from abroad, members of the Roma minority, high-school graduates from rural areas and from small towns (less than ten thousand inhabitants) (Law 1/2011, art. 205, pt. 2, 4, and 6).

\footnotetext{
11 We consider our understanding of equity to be consistent with specific policies of the European Commission (Bevc and Uršič 2008), and of the OECD (Field et al. 2007), even though the terminology may differ.

12 A recent inventory of the inequalities of participation in higher education can be found in Salmi et al. (2014).
} 


\subsection{Data and Methodology}

Data on the distribution of the specified subsidies is retrieved mainly from two sources. Data on student population and study grants is retrieved from the National Council for Financing Higher Education (CNFIS), a buffer organisation with responsibilities in the field. The data cover the entire population, which represents enrolments in this case. For a numerical perspective on the evolution of scholarships and accommodation facilities in student dormitories we analyse sample data from the 2011 wave of the longitudinal survey conducted for the "quality barometers" of the Romanian Agency for Quality Assurance in Higher Education (ARACIS) (Vlăsceanu et al. 2011; Păunescu et al. 2011). The respondents of the 2011 wave were bachelor or master students, or graduates of bachelor and master programme from the 2009 and 2010 waves. Other sources are indicated in the text. In terms of methodology, we used univariate analysis and we tested the estimates with the nonparametric chi-square test. We calculated the margin of error for the 0.95 confidence level using the standard formula (Agresti 2007, 9-10).

Where possible, we contrast our findings with the results of a survey conducted in 2000, on bachelor students in state and private universities (Vlăsceanu and Dima 2000, 63-65). On one hand, the samples are not exactly identical: the 2000 sample covers bachelors, while the 2011 one covers both bachelors and masters. On the other hand, the structure of the studentships was different: in 2000 the Bologna bachelor-master-doctorate cycles were not implemented; the credentials of preBologna bachelor are equivalent nowadays to master degrees. The proportion of the 2000 equivalent of post-bachelor students in the relevant population should be considerably lower than that of the 2011 master students, as it can be seen in the Table 1.

Due to these reasons we consider that the two surveys have a considerable degree of overlap. We also note here that both data bases contain self-declarations.

We underline that we do not strictly compare the estimates of the 2000 and 2011 survey; we rather present the figures advanced on the basis of the 2000 survey as references for the interplay between student support policy options and inequalities in higher education, not as an accurate statistical comparison. We also use the 2000 estimates as references for some of the chi-tests.

\subsection{Study Grants: Criteria}

The post-1989 students fall under two categories: (1) tuition paying; and (2) state subsidised, or "budgeted" students. The state covers costs of education for only a part of the students enrolled in public universities through direct transfers to the universities, as the major component of the public funding. We will refer to the subsidised students as beneficiaries of study grants. Private universities receive no budget for education costs from the state, and therefore their students cannot 
Table 1 Bachelor and master/ post bachelor enrolments 1999-2000 and 2009-2010 (data source: CNFIS)

\begin{tabular}{l|l|l|l}
\hline Academic & $\begin{array}{l}\text { Bachelor and master/ } \\
\text { 2000 correspondent of master } \\
\text { (total) }\end{array}$ & $\begin{array}{l}\text { Bachelor } \\
(\%)\end{array}$ & Master/ correspondent (\%) \\
\hline $1999-2000$ & 463,507 & 98 & 2 \\
\hline $2009-2010^{\mathrm{a}}$. & 914,530 & 85 & 15 \\
\hline
\end{tabular}

${ }^{a}$ Data for private universities for the academic years after 2010 were not published

appropriate study grants under the arrangements we discuss here. We underline that there is no intermediary category of students, whose costs of education are covered partially by the state, or from another source. An agency responsible for student loans was set up in 2009 as an alternative ways to finance higher education (Cabinet Ordinance 5/2009), but student loans were still ineffective at this writing.

The value of a study grant is calculated by a special body (the National Higher Education Funding Council-CNFIS) based on a sophisticated formula, and it varies with the field of study, the study cycle, the teaching language as well as the quality ${ }^{13}$ of the study programme offered by an university (Miroiu and Vlăsceanu 2012, 795-800). Irrespective of the calculated value of the study grants, students are not supposed to pay additional money out of their own pockets to cover their tuition fees. ${ }^{14}$ Therefore study grants can be seen as the only instrument for covering the costs of tuition in Romania. Study grants have a rather abstract character, given the fact that the money value of the grant does not flow through the recipient students' bank accounts.

Each study programme is allotted a certain number of study grants, the so called "budgeted positions". The norm is that "budgeted positions" for first year students are "occupied" on the basis of the entrance examinations results. Universities are free to decide their entrance requirements and procedures, but they are bound to distribute the first year study grants on the basis of the admittance results (MEN 2013). For the subsequent years, the norm is that the study grants are distributed on the basis of students' academic results in the previous year. Quotas for Roma minority and for Romanian ethnics from Moldova and the Balkans have a separate regime. Exceptionally, study grants are distributed as a form of affirmative action to socially disadvantaged students. We have identified also exceptions from the general rule of yearly re-distribution based on merit: at the Technical University in

\footnotetext{
13 Until 2011, the financing methodologies contained the so-called "quality indicators", discussed at length in Vîiu and Miroiu (2014). The ranking of study programmes instituted by the 2011 Education Law was intended to provide indicators for the quantification of quality.

14 In practice, universities charge administrative fees to budgeted students as well. The evidence collected by ANOSR (2010) indicates that the value and types of such "hidden taxes" presents ample fluctuations, but it generally represents a small fraction of the value of the tuition.
} 
Cluj the students who are considered disadvantaged according to a set of social standards ${ }^{15}$ keep their study grants if they accumulate enough ECTS credits to pass the year (UTCN 2012).

\subsection{Study Grants: A Historical Perspective}

According to CNFIS data, the number of study grants has almost doubled in the nineties, it reached a high plateau delimited by two maximum points in 1999/00 and 2002/03. Afterwards the data manifests a decreasing tendency, but the values remained high. The data for tuition paying students has a parabolic shape, with the maximum in 2007/08. It intersects the study grants' line in 2010/11. A CNFIS report argues that the number of study grants reflects some past equilibrium from a period when enrolments were higher; both enrolments and secondary education graduations dropped, but the number of study grants did not drop proportionally, resulting in lowering the percentage of tuition paying students (CNFIS 2013, 47) (Fig. 1).

The present situation inherits many characteristics from the last decades of the communist regime, when higher education was entirely state-provided and tuitionfree, but under-dimensioned in relation to the demand. The distribution of study grants and academic admittance and progression were perfectly aligned.

As early as 1993 public universities were allowed to enrol additional students willing to pay the tuition fees. Following the enforcement of the new regulation, ${ }^{16}$ a small debate emerged in the public sphere. Some argued that the number of statebudgeted students was extremely restrictive, and that public universities were able to offer more education for young people above the state support. However, the view that state education must be free became compelling, and soon the Cabinet decided to subsidise entirely all students. It was only in 1998 when public universities started again to enrol students who paid themselves the tuition fee. During the first years of co-habitation between "budgeted" and tuition paying students, study grants were distributed based on the admittance score and they were kept until graduation, provided the student passed the year. Practically, budgeted and tuitionpaying students were offered the same education, but the rules governing the funding of their education costs where different, and did not allow for transfers between the two categories. The rules governing the financing of budgeted students were inherited from a completely public, free-of-charge higher education, while

15 Students are considered disadvantaged if they fulfill at least one of the following criteria: (1) are orphans or come from placement centers or child care; (2) come from single parent families and their income per family member is lower than the minimum wage; and (3) come from families with more than one student at all levels of education and their income per family member is lower than the minimum wage.

16 See http://www.cdep.ro/pls/legis/legis_pck.htp_act_text?idt=13686. 


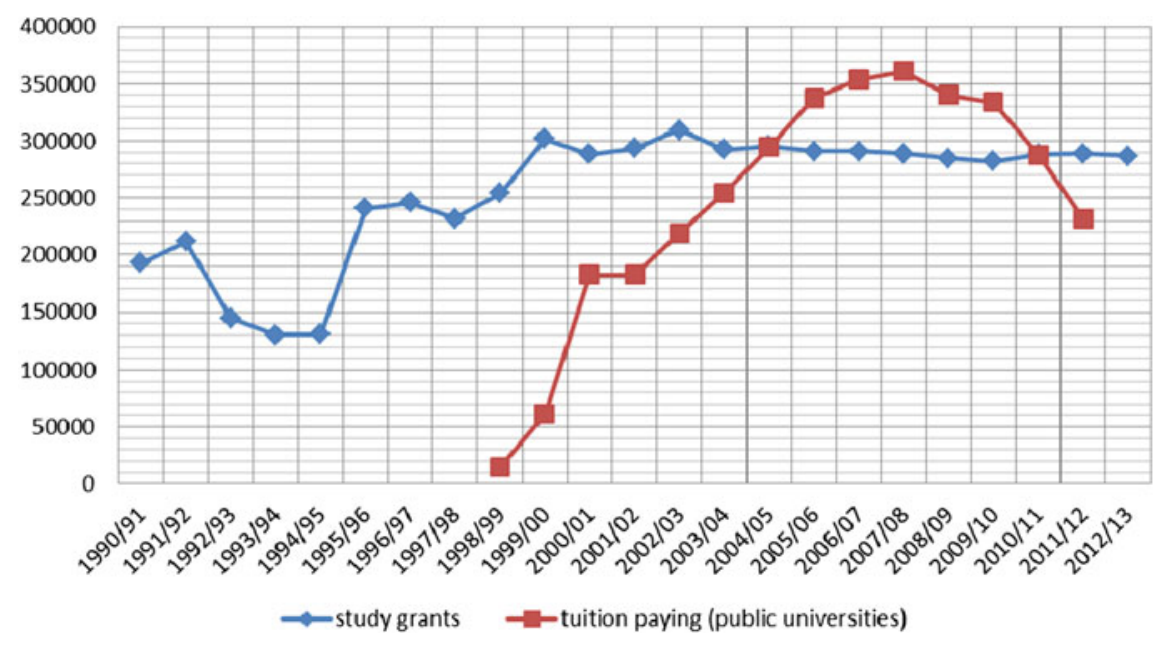

Fig. 1 Study grants and tuition paying students in public universities (1990-2012). Data sources: CNFIS and the ministry responsible for higher education

tuition-paying students were following rules resembling the arrangements in private universities. $^{17}$

The rule of reshuffling study grants after the end of each academic year represented a notable (and the single!) departure from the initial stage of institutional amalgamation. Yet it preserved the sharp distinction between students who receive full support and students who get no support to cover tuition fees. Moreover, it preserved merit as the staple criterion of evaluation, and in theory it should have provided a strong incentive to reward the better students. An attempt to change the status quo was associated with the implementation of the new law on education passed through the Parliament in 2011. The main proponent of the change was Cătălin Baba, minister of education in the M.R. Ungureanu cabinet. He proposed to allow universities to decide on the number and the value of study grants, as well as on the criteria according to which they were to be distributed to students, within the budget allocated. (Clearly, this approach leaves room for criteria other than merit.) One of his most important proposals was to allow universities to offer students full or only partial study grants. ${ }^{18}$ As a result, the state support a student could have received would have covered only a part of the tuition fee. However, with the fall of the Ungureanu Cabinet in May 2012, the proposed changes were abandoned.

\footnotetext{
17 We have identified few public universities in which tuition-paying students are still not eligible for scholarships or where subsidised students are still given priority in the distribution of other subsidies (places in student dormitories or in-town transportation discounts).

18 See for example http://www.evz.ro/detalii/stiri/soc-in-facultati-studii-cu-bani-de-acasa- 975224 . html?utm_source=export\&utm_medium=rss\&utm_campaign=b13. The idea of introducing partial study grants was first presented in Miroiu (2005).
} 
The sources of financing higher education expenses in the arrangements we have described above are public, i.e., subsidies, or private, i.e., contributions from students and their families. In the context of this dichotomy both policy-makers and researchers ${ }^{19}$ have advanced the alternative of student loans. In fact, student loans have been instituted on paper in early 1998-1999 (Cabinet Ordinance 105/1998, Law 193/1999). We underline that one of the mandatory requirements to receive a student loan was that the applicant's income per family member should be lower than the minimum wage in the economy. Another criterion was that the applicant should have passed all exams from previous years. The student loan was instituted with reference to both equity and quality thresholds. The legislation was, however, ineffective (Explanatory Memorandum 2009) and another attempt to alter the status-quo was made in 2007, when the Romanian authorities requested the assistance of the World Bank in setting up an operational student loans system. Following the recommendations of the international experts, a designated agency was set up in 2009 (Cabinet Ordinance 5/2009), but this step proved to be insufficient as well. Shortly after its set up, the agency was given additional responsibilities to manage some very specific scholarships, which reach very few students (Cabinet Decision 1402/2009), while student loans are still ineffective as of this writing. ${ }^{20}$

To conclude, the merit-based distribution of study grants and their alignment with the entrance examination represented a central policy option; while needssensitive alternatives have been considered, they would have departed considerably from the status quo and were not adopted. Another alternative that promised to alter significantly the existing situation was the setting up of a student loan system. Although the legislative framework for student loans was firstly established in 1998-1999 and was followed by other attempts of institutionalisation, the system is still ineffective. For nearly a quarter of a century, the Romanian higher education has been experiencing only incremental changes in the financing of higher education expenses, mostly limited to minor adjustments in the distribution of study grants.

\subsection{Scholarships}

The legislative framework which institutes scholarships in Romanian universities is heavily prescriptive, detailed and not coherent in some of its aspects. ${ }^{21}$ The most common and long-lived types of scholarships are merit-based scholarships and the so called "social scholarships", which are needs-based. Both types (partially) cover

\footnotetext{
19 See Voicu (2007), Vlăsceanu and Dima (2000).

20 See http://www.roburse.ro/agentia.php, accessed in September, 19th, 2013.

21 The legislative acts which regulate these types of scholarships are The Education Law (1/2011) and the Cabinet Decision 558/1998. An example of incoherence is the different definitions they provide to needs, in the context of equity approaches.
} 
the students' living expenses. The legislative frame establishes the categories of students eligible for social scholarships, as well as some general guidelines for the categories of merit-based scholarships. Merit is understood as academic achievement and outstanding performance in the field of study. A more detailed description of the categories of scholarships can be found in Salmi et al. (2014). Universities are allowed to decide on how many scholarships to distribute within each type, and on the value of each type of scholarship. The government allots a single budget line for all types of scholarships and the universities have the freedom to supplement it. The distribution methodologies are also up to the universities. Universities can decide to award other types of scholarships from their own funds. ${ }^{22}$

A report conducted by CNFIS (2011) found that in 2011 all the surveyed universities allotted to needs-based scholarship the smallest value among all types of scholarships. The average needs-based scholarship amounted to 184 lei, which represented only $32 \%$ of the estimated monthly expenses on meals and accommodation. On average, the highest value a student could cumulate from needs and merit-based scholarships amounted to $87 \%$ of the estimated costs for accommodation and meals.

We calculated the proportions associated with each type of scholarship in the 2011 data base. The estimates and the corresponding margins of error for a 0.95 confidence level can be found in the Table 2. We added to the table the values estimated by Vlăsceanu and Dima, for the academic year 1999-2000 (2000, 24).

Two observations are immediate: (1) the proportion of students who receive a form of merit-based scholarship is substantially higher than that of the beneficiaries of needs-based scholarships, and (2) in 2011 scholarships were distributed on a more extended scale than in 2000, both in terms of numbers and of the proportions of the students who appropriated them.

If students from private universities are excluded from the analysis, we obtain ${ }^{23}$ the following proportions and the corresponding margins of error for the 0.95 confidence level: $32.0 \pm 2.1 \%$ of the students received a form of scholarship. $27.1 \pm 2.0 \%$ of the students received a form of merit-based scholarship, while a mere $4.9 \pm 1.0 \%$ of them received needs based scholarships.

A brief review of the history of post-1989 higher education in Romania reveals that the scholarships' orientation towards quality has resisted reform attempts. In 1996 the Romanian Government received a loan from the World Bank under a project $^{24}$ aimed to support the overall goals of the Government's program for reforming higher education. One of the main objectives was to improve access to higher education for talented but needy students, while mitigating the adverse

\footnotetext{
22 For example, a partnership of three universities (“Al. I. Cuza” University in Iași , Babes-Bolyai University in Cluj and West University in TimiȘoara) grant scholarships for female master students. See http://www.rsf.uaic.ro/index.php/component/content/article/47, accessed on August 4, 2013.

23 The null hypothesis was rejected (the proportions for public universities do not differ from the proportions corresponding to both public and private universities), $p<0.001$, valid cases: 1471 .

${ }^{24}$ The project was entitled The Reform of Higher Education and Research Project.
} 
Table 2 Scholarships, academic years 1999-2000 and 2010-2011

\begin{tabular}{l|l|l|l|l}
\hline $\begin{array}{l}\text { Academic } \\
\text { year }\end{array}$ & $\begin{array}{l}\text { Students receiving a } \\
\text { form of scholarship } \\
(\%)\end{array}$ & $\begin{array}{l}\text { Estimated } \\
\text { number of } \\
\text { scholarships }\end{array}$ & $\begin{array}{l}\text { Merit based } \\
\text { scholarships } \\
(\%)\end{array}$ & $\begin{array}{l}\text { Needs-based } \\
\text { scholarships } \\
(\%)\end{array}$ \\
\hline $1999-2000$ & $20 \pm 2.0$ & $92701 \pm 9270$ & $18 \pm 1.9$ & $2 \pm 0.7$ \\
\hline $2010-2011$ & $27.6 \pm 2.0$ & $\begin{array}{l}246923 \pm 18 \\
291^{\mathrm{a}}\end{array}$ & $23.5 \pm 1.9$ & $4.1 \pm 0.9$ \\
\hline
\end{tabular}

The null hypothesis was rejected (reference: Vlăsceanu and Dima $(2000,24)), p<0.001$, valid cases: 1778

a Again we lacked data corresponding to academic year 2010-2011; we used data corresponding to 2009-2010 instead

consequences of relying on cost recovery schemes. It was recommended to shift the allocation of student support from an approach based to a major extent on merit to a combination of need- and merit-based allocation. The target was to allocate no less than $20 \%$ of the scholarships to needy but talented students, while limiting the threshold for merit-exclusive scholarships to only $3 \%$ of overall student support budget (World Bank 1996, 94).

However, these recommendations have never been implemented. ${ }^{25}$ A Cabinet Decision which included the move to a need- and merit-based approach in allocating the scholarships was presented to the Isărescu Cabinet in November 2000, but was not approved. Meanwhile, student associations (consisting mainly of students in public universities) fiercely opposed the change (World Bank 2003, 6).

The different points discussed above converge to the conclusion that scholarships have been distributed preponderantly on merit since the early nineties. A central policy alternative that departed considerably from the status quo was opposed on several fronts, especially by some of the student representatives. However, the context in which the revision had been considered was significantly different compared to the current context: needs-based approaches were quite frequently labelled an expression of communist mentality, ${ }^{26}$ while the student organisations which opposed change were operating in some of the public universities, where tuition fees were not implemented at that moment.

\footnotetext{
25 As noted by the World Bank $(2003,16)$ in 2003 the scholarship scheme was only slightly revised. The adjustment consisted in extending the allocation for needs-based scholarships to $30 \%$ of the total funds for scholarships.

${ }^{26}$ In fact, the actions undertaken in Romanian universities during the communist period represented an extreme form of affirmative action, often marked by illiberal approaches. In the late forties and the early fifties measures were taken to increase participation rates for students from worker and peasant families: entrance quotas, limited access to non-vocational faculties for the ones with so-called "unhealthy social origin", differentiated routes to graduation, etc. (Bozgan 2004, Vese 2012).
} 


\subsection{Accommodation}

Universities' regulations regarding the distribution of accommodation facilities contain references to both merit and needs. Moreover, some universities chose to prioritise different categories of students in the distribution of accommodation facilities, which include: married students (The Baptist Institute in Bucharest), children of employees in the public education system ("Ștefan cel Mare" University in Suceava), student representatives ("Babeș-Bolyai" University in Cluj, Craiova University), international students ("Transilvania" University in Braşov), students with achievements in sports (The University of Agriculture and Veterinary Medicine in Cluj), etc.

Vlăsceanu and Dima $(2000,27)$ estimated that $28 \pm 2.8 \%$ of the students were living in dormitories in 2000. They identified a decreasing tendency in regards to the percentage of students who benefit from such accommodation facilities, from 50 $\%$ in $1994 .{ }^{27}$ Our estimate ${ }^{28}$ based on survey data for 2011 suggests that $37 \pm 2.2 \%$ of the students in both public and private universities receive such benefits.

An additional detail is necessary to complete the perspective: we estimate that $42 \pm 2.3 \%$ of the total population of the 2011 students lived either with their parents, or in their own apartments. If we equalise the maximal unsatisfied demand with the percentage of students who rent or have other living arrangements, then $64 \pm 2.2 \%$ of the overall demand was satisfied in 2011; for public universities the demand was satisfied in a proportion of $68 \pm 2.1 \%$.

If the current tendency of decreasing enrolments continues, we can expect the demand to be satisfied in even higher proportions. This situation can be explained as a consequence of the past decade investments in infrastructure, which were dimensioned to enrolments in the maximal range.

\subsection{The Appropriation of Student Subsidies: A Statistical Perspective}

The literature we reviewed provides snapshots of inequalities of participation in higher education at different moments starting from the early nineties until recently (EACEA et al. 2012, 78, Vlăsceanu et al. 2011, 133, 277-278, Voicu 2007, 23, Vlăsceanu and Dima 2000, Pasti 1998, 43-44, 145-148). The conclusions of these various studies indicate that family background-i.e., parents' education, parents' residence in rural or urban localities, and income per family member - had a

\footnotetext{
27 This tendency may result from the increase in the number of students in public universities in the period. Due to lack of resources, the number of places in dormitories roughly remained constant in the nineties.

28 The null hypothesis was rejected (Vlăsceanu and Dima (2000, 24)), $p<0.001$, valid cases: 1791.
} 
substantial and pervasive impact on participation in Romanian higher education. The policy reports we have consulted provide converging images e.g. (MECTS (2012, 12), Jongbloed et al. (2010, 510)).

Research on recent years' cohorts points to the fact that some of the past discrepancies in terms of participation rates tended to decrease as enrolments expanded. Voicu and Vasile (2010) argue that rural-urban attainment inequalities decreased considerably between 2000 and 2006. ${ }^{29}$ The tendency they identify interrupts a previously stable trend of increasing inequalities which started in the early seventies and culminated in the nineties. Vlăsceanu et al. (2011) found that 67 $\%$ of the 2010 students come from families whose level of education is lower than higher education and interpreted their estimates as indication of ascendant social mobility.

We have also reviewed the literature on the contribution of student subisidies to the reproduction of the social structure within higher education. Pasti (1998) argued that study grants' distribution contributed to the escalation of the social inequalities in higher education. He concluded that the financing of higher education represented a state policy which redistributed income from the poorer parts of the population to the wealthiest $20 \%$ (Pasti 1998, 43-44). Vlăsceanu and Dima (2000, 24-25) found that scholarships were generally serving to top up the income of the better off students, serving rather as "extra pocket money". They also found that the composition of the student body resembled the social structure of the wealthiest two deciles of the Romanians (Vlăsceanu and Dima 2000, 25). Their findings indicate that the distribution of study grants increased inequalities in higher education.

In this second part of the article we assess the proportions in which the categories of students defined by the three "equity" variables appropriate student subsidies. We explore which categories of students are "over- and under-represented" as beneficiaries of student subsidies. In this respect we take as reference the estimates of the proportions in which the categories defined by the three variables are represented in the overall student cohort. Our aim is to understand the contribution of the current arrangements regarding student subsidies to the dynamics of the inequalities in Romanian higher education.

\subsection{Data}

The analysis is carried out on the survey data we used to discuss the numerical evolution of scholarships and accommodation facilities in the previous part of the article.

\footnotetext{
29 The authors warn that the methodology they use may overestimate attainment rates for student with a rural background for the period between 2000 and 2006 .
} 


\subsection{Variables}

We constructed the independent variables as indicators of students' socio-economic background: residence (rural-urban), parents' education and income.

Parents' education is seen as being determinant for the social class and family income (Voicu and Vasile 2010,17) and it is used as predictor for the reproduction of the social structure (Vlăsceanu et al. 2011, Vlăsceanu and Dima 2000, Voicu and Rusu 2011, 143-147). We defined parents' education as a dichotomous variable. We labelled "higher education" the cases where at least one of the parents has graduated a bachelor programme or higher. The rest of the cases are labelled "lower". We discarded the cases in which there was no valid answer for any of the parents, or where one parent's level of education was below higher education and there was no valid answer for the other. The latter cases could belong to both of the defined categories.

Rural-urban inequalities are seen as pervasive in Romanian higher education, due to a complex set of factors which include the low quality and inaccessibility of secondary education in rural areas, the physical distance from universities, and due to other factors related to the context of the family (Voicu and Vasile 2010, 11). We defined rural-urban background as a dichotomous variable, where "rural" stands for the cases in which parents live in rural areas and "urban" represents the rest of the cases. Alternative definitions are used in the literature e.g. the previously quoted authors distinguish rural from urban students on grounds of their place of birth. Our definition is similar to that of the 2011 national census ${ }^{30}$ and our option is grounded on issues of data comparability. We removed orphans and students whose parents live in another country.

Family income is relevant not only from the perspective of the social background, but also because the strength of material incentives is in theory affected by the available financial resources. The only variable in the 2011 data base which referred to income was the monthly personal income. We removed the cases which corresponded to graduates which were questioned in the 2009 and 2011 waves, as their monthly income at the time of answering the questionnaire, mostly from salaries, are irrelevant for the distribution of students according to income. We also removed three cases, whose declarations were implausible. ${ }^{31}$ We note that the declared personal income is not necessarily equal to the income per capita, which is the variable used in official statistics and in the 2000 survey. Therefore, the proportions we estimate cannot be compared with Vlăsceanu and Dima’s (2000) estimates, nor with the income distribution in Romania's population.

We constructed the dependent variables as dichotomous variables which describe if the respondent benefits from student subsidies or not. We analyse the

\footnotetext{
$30 \mathrm{http}: / /$ www.recensamantromania.ro/rezultate-2/, Accessed on the 25th of September, 2013.

31 One respondent declared an income of $1 \mathrm{RON}$, while two declared they were receiving a form of scholarship, but their personal declared income was lower than the minimum scholarship calculated by CNFIS (2011).
} 
distribution of the subsidies described in the first part of the article: study grants, scholarships and accommodation. We are interested only in those students who are eligible to receive the subsidies, therefore we removed from the sample the responses corresponding to students from private universities. We analysed only the appropriation of merit-based scholarship, as the "social scholarships" is supposed to be appropriated exclusively by needy students. We kept in the sample the recipients of needs-based scholarships, as their removal would have modified the proportions within the reference population.

\subsection{Methodology and Results}

We opted for using bivariate analysis, plus the chi-square test and the calculation of margins of error for the 0.95 confidence level. In the construction of the null hypotheses we opted for two different approaches: one for the dichotmous variables (parents' education and parents' residence) and one for the declared personal income (numerical variable).

For the dichotomous variables, we firstly estimated the distributions within public universities. According to our calculations, $17.6 \pm 1.7 \%$ of the students in public universities are coming from rural areas. For reference, the proportion of the 19-25 population who is recorded as living in rural localities reaches $42.7 \%$, according to according to official data (INS 2013). We estimate that $62.8 \pm 2.2 \%$ of the students are from parents without higher education, while $88 \%$ of the adult population did not graduate higher education, according to Voicu and Rusu (2011, 144). We used the references for the overall population as null hypotheses for chisquare tests; the calculations are presented in the Table 3. Our estimates indicate that the least well off categories are under-represented amongst students of public universities, ${ }^{32}$ in relation to both parents' residence and parents' higher education attainment. The results are highly significant.

In the second stage we estimated the proportions in which each category defined by the two "equity" variables appropriates the subsidies. We tested the estimates using chi-square tests, where the null hypothesis is that each category defined by the two variables appropriates subsidies in proportions equal to their share in the student cohort within public universities. The results are presented in Tables 4 and 5 .

We opted for a different sequence of operations for the income variable. We transformed the numerical variable in a categorical one, by splitting the data into quintiles. ${ }^{33}$ The percentages associated with each quintile and values' range are

\footnotetext{
32 We note that the inclusion of students from private universities in the sample does not change significantly the situation: the estimate for the proportion of students from parents living in urban areas is $16.2 \pm 1.7 \%$, while the figure for the proportion of students from parents who did not attain higher education is $62.9 \pm 2.2 \%$.

33 We use "quintile" to refer to the sets of data delimited by the values of the quintiles.
} 
Table 3 References for parents' residence and parents' education: proportions within students from public universities

\begin{tabular}{l|l|l|l|l|l}
\hline $\begin{array}{l}\text { Parents' } \\
\text { residence }\end{array}$ & Rural (\%) & Urban (\%) & $\begin{array}{l}\text { Valid } \\
\text { cases }\end{array}$ & $\begin{array}{l}\text { Null } \\
\text { hypothesis }\end{array}$ & Significance \\
\hline Proportion & $17.6 \pm 1.8$ & $82.4 \pm 1.8$ & 1,426 & $\begin{array}{l}\text { Rejected } \\
(42.7 \%)\end{array}$ & $p<0.001$ \\
\hline $\begin{array}{l}\text { Parents' } \\
\text { education }\end{array}$ & $\begin{array}{l}\text { Lower } \\
(\%)\end{array}$ & $\begin{array}{l}\text { Higher ed. } \\
(\%)\end{array}$ & $\begin{array}{l}\text { Valid } \\
\text { cases }\end{array}$ & & \\
\hline Proportion & $62.8 \pm 2.2$ & $37.2 \pm 2.2$ & 1,338 & $\begin{array}{l}\text { Rejected } \\
(76 \%)^{\mathrm{a}}\end{array}$ & $p<0.001$ \\
\hline
\end{tabular}

${ }^{a}$ We constructed the reference maximising the higher education attainment rate per family, namely by approximating the higher education attainment rate per family with the double of the individual rate, in the overall population. In practical terms, our approximation implies that each adult with higher education is married to someone with lower level of education, which is highly unlikely

Table 4 Appropriation of subsidies according to parents' residence (public universities)

\begin{tabular}{l|l|l|l|l|l}
\hline $\begin{array}{l}\text { Proportions } \\
\text { in which } \\
\text { subsidies are } \\
\text { appropriated }\end{array}$ & \multicolumn{2}{|l|}{ Parents' education (\%) } & \multicolumn{2}{l|}{$\begin{array}{l}\text { Chi square test results } \\
\text { (Degree of freedom =1) }\end{array}$} & \multicolumn{2}{l}{$\begin{array}{l}\text { Standardised } \\
\text { residual }\end{array}$} \\
\cline { 2 - 6 } & Lower & Higher ed. & Lower & $\begin{array}{l}\text { Higher } \\
\text { ed. }\end{array}$ \\
\hline Study grants & $61.2 \pm 2.2$ & $38.8 \pm 2.2$ & $\begin{array}{l}\chi 2(\mathrm{~N}=1,047)=3.545, \\
p=0.060, \\
\text { null hypothesis validated }\end{array}$ & -0.6 & 0.7 \\
\hline $\begin{array}{l}\text { Scholarships } \\
\text { (merit) }\end{array}$ & $59.5 \pm 2.3$ & $40.5 \pm 2.3$ & $\begin{array}{l}\chi 2(\mathrm{~N}=380)=2.175, \\
p=0.140, \\
\text { null hypothesis validated } \\
2(\mathrm{~N}=595)=11.836, \\
p=0.001,\end{array}$ \\
$\begin{array}{l}\text { Student } \\
\text { dormitories }\end{array}$ & $67.9 \pm 2.1$ & $32.1 \pm 2.1$ & -0.8 & 1.6 \\
\hline
\end{tabular}

Table 5 Appropriation of subsidies according to parents' education (public universities)

\begin{tabular}{|c|c|c|c|c|c|}
\hline \multirow{2}{*}{$\begin{array}{l}\text { Proportions } \\
\text { in which } \\
\text { subsidies are } \\
\text { appropriated }\end{array}$} & \multicolumn{2}{|c|}{ Parents' residence } & \multirow[t]{2}{*}{$\begin{array}{l}\text { Chi square test results } \\
(\text { Degree of freedom }=1 \text { ) }\end{array}$} & \multicolumn{2}{|c|}{$\begin{array}{l}\text { Standardised } \\
\text { residual }\end{array}$} \\
\hline & Rural (\%) & Urban (\%) & & Rural & Urban \\
\hline Study grants & $18.7 \pm 1.7$ & $81.3 \pm 1.7$ & $\begin{array}{l}\chi 2(\mathrm{~N}=1,049)=1.454 \\
p=0.228 \\
\text { null hypothesis validated }\end{array}$ & 0.5 & -0.2 \\
\hline $\begin{array}{l}\text { Scholarships } \\
\text { (merit) }\end{array}$ & $20.0 \pm 1.8$ & $80.0 \pm 1.8$ & $\begin{array}{l}\chi 2(\mathrm{~N}=370)=1.752 \\
p=0.186, \\
\text { null hypothesis validated }\end{array}$ & 1.0 & -0.5 \\
\hline $\begin{array}{l}\text { Student } \\
\text { dormitories }\end{array}$ & $23.2 \pm 2.0$ & $76.8 \pm 2.0$ & $\begin{array}{l}\chi 2(\mathrm{~N}=590)=22.366 \\
p<0.001, \\
\text { null hypothesis rejected }\end{array}$ & 3.3 & -1.5 \\
\hline
\end{tabular}


Table 6 Income quintiles

\begin{tabular}{l|l|l|l|l|l|l}
\hline Quintile & $\begin{array}{l}\text { Income range } \\
(\text { RON })\end{array}$ & $\begin{array}{l}\text { Percentage in the } \\
\text { sample }\end{array}$ & $\begin{array}{l}\text { Rural } \\
(\%)\end{array}$ & $\begin{array}{l}\text { Urban } \\
(\%)\end{array}$ & $\begin{array}{l}\text { Lower } \\
(\%)\end{array}$ & $\begin{array}{l}\text { Higher } \\
\text { education } \\
(\%)\end{array}$ \\
\hline i & $10-350$ & 18.1 & 82.6 & 17.4 & 70.1 & 29.9 \\
\hline ii & $400-555$ & 21.4 & 83.4 & 16.6 & 63.1 & 36.9 \\
\hline iii & $600-999$ & 15.6 & 77.0 & 23.0 & 64.5 & 35.5 \\
\hline iv & $1,000-1,150$ & 22.9 & 84.3 & 15.7 & 56.2 & 43.8 \\
\hline v & $1,200-10,000$ & 22.1 & 84.9 & 15.1 & 63.5 & 36.5 \\
\hline $\begin{array}{l}\text { Valid } \\
\text { cases }\end{array}$ & & 1,001 & 936 & & 953 & \\
\hline
\end{tabular}

Table 7 Appropriation of subsidies according to income (public universities)

\begin{tabular}{|c|c|c|c|c|c|c|c|}
\hline \multirow[t]{2}{*}{ Quintile } & \multirow{2}{*}{\begin{tabular}{|l} 
Student \\
cohort \\
(reference)
\end{tabular}} & \multicolumn{2}{|c|}{ Study grants } & \multicolumn{2}{|c|}{ Scholarships } & \multicolumn{2}{|c|}{ Student dormitories } \\
\hline & & Yes $(\%)$ & $\begin{array}{l}\text { Std. } \\
\text { residuals }\end{array}$ & Yes $(\%)$ & $\begin{array}{l}\text { Std. } \\
\text { residuals }\end{array}$ & Yes $(\%)$ & \begin{tabular}{|l|} 
Std. \\
residuals
\end{tabular} \\
\hline $\mathrm{i}$ & $18.1 \pm 1.8$ & $19.5 \pm 1.8$ & 0.0 & $24.4 \pm 2.0$ & 1.9 & $18.4 \pm 1.8$ & -0.4 \\
\hline ii- iv & $61.9 \pm 2.2$ & $63.3 \pm 2.2$ & 0.5 & $60.7 \pm 2.2$ & -0.3 & $66.4 \pm 2.2$ & 1.2 \\
\hline $\mathrm{v}$ & $22.1 \pm 1.9$ & $17.2 \pm 1.7$ & -0.9 & $14.8 \pm 1.6$ & -1.4 & $15.2 \pm 1.6$ & -1.7 \\
\hline \multicolumn{2}{|c|}{$\begin{array}{l}\text { Chi square test } \\
(\mathrm{df}=2)\end{array}$} & \multicolumn{2}{|c|}{$\begin{array}{l}\chi 2=5.172, p=0.075 \\
\mathrm{~N}=853\end{array}$} & \multicolumn{2}{|c|}{$\begin{array}{l}\chi 2=8.059, p=0.018 \\
\mathrm{~N}=858\end{array}$} & \multicolumn{2}{|c|}{$\begin{array}{l}\chi 2=9.219, p=0.010 \\
\mathrm{~N}=858\end{array}$} \\
\hline \multicolumn{2}{|c|}{ Null hypothesis } & \multicolumn{2}{|c|}{ Validated } & \multicolumn{2}{|c|}{ Rejected } & \multicolumn{2}{|c|}{ Rejected } \\
\hline
\end{tabular}

presented in the table below. For informative purpose we also included in the Table 6 the distribution according to parents' residence and parents' education.

We note that most probably the data does not reflect in-kind income. The questionnaire did not include qualitative questions on how costs associated with being a student are covered. However, it is a common strategy that students receive other forms of in-kind support from their families, such as food, clothing or payment of telephone bills, which are not reflected in the current data. Therefore, probably the values corresponding to at least the lowest quintile would grow if these forms of in-kind support are included.

Following the transformation of the variable, we estimated the proportions in which students from lowest and highest quintiles appropriate subsidies. We tested the results with chi-square test; the null hypothesis was that the appropriation of student subsidies is not sensitive to income. The references are in the third column (percentages within the sample). The results are presented in the Table 7.

\subsection{Summary of Empirical Findings}

The null hypotheses consisted in affirming that the proportions in which subsidies are appropriated by each category of students defined by the "equity" variables equals the correspondent level of representation in the cohort within public 
Table 8 Appropriation of merit-based scholarships by income categories: odds ratio

\begin{tabular}{l|l|l}
\hline Quintiles & Lowest: highest & Middle: highest \\
\hline Odds ratio & 1.94 & 1.33 \\
\hline
\end{tabular}

universities. For study grants the null hypothesis was confirmed in relation to all independent variables. For scholarships, the null hypothesis was validated in relation to parents' residence and parents' education. The null hypothesis was rejected for the appropriation of scholarships according to income categories. These findings indicate there is no evidence that the current distribution pattern of study grants and scholarships creates advantages for the categories defined by the three variables associated with family background, with a notable exception: the appropriation of merit-based scholarships is sensitive to income. We stress again that the income variable in our sample refers to the monthly income the students declare and it is not comparable with the distribution of income in the overall population. We find important to remind that, overall, the better off categories of population are over-represented among the students, which implies that a distribution pattern which is not sensitive to the family background according to the construction of our analysis contributes to the maintenance of the existing social structure within the student cohort in public universities i.e. the under-representation of the least well off categories.

The standardised residuals indicate a slight over-representation of students from the lowest quintile amongst those who benefit from merit-based scholarships and a slight under-representation of those from the highest quintile. The low values of the residuals $(<2)$ requires caution in interpreting the finding as an indication of association (Agresti 2007, 38-39). We calculated odds ratio between lowest and middle quintile, and the highest quintile. The results are presented in the Table 8:

The odds that a student from the lowest quintile appropriates merit-based scholarships in public universities are 1.94 higher than those for a student from the highest quintile. The odds ratio between middle income and highest income students (1.33) are lower that the odds ratio between the lowest and the highest income students (1.94). If talents are evenly distributed across the population and the wealthier ones stand more chances to benefit of an environment which stimulates learning, then this finding indicates that wealthier students could find scholarship less attractive than their less well off counterparts. This association is consonant with the idea that the strength of the incentive depends on how the recipient perceives the value of the subsidy, which raises concern regarding the efficiency of merit-based scholarships in terms of motivating achievements. In fact, we estimate ${ }^{34}$ that $55.9 \pm 2.3 \%$ of the students in public universities which are located in the highest quintile declare they derive their most important share of income from employment or self-employment, while the reference for the share of the sample corresponding to public universities is $23.3 \pm 1.9 \%$; for other $38.5 \pm 2.2 \%$ of the

34 The estimates are highly significant: $\chi^{2}=203.550, p<0.001, \mathrm{~N}=855, \mathrm{df}=6$. 
Table 9 Appropriation of study grants according to income categories: odds ratios

\begin{tabular}{l|l|l}
\hline Quintiles & Lowest: highest & Middle: highest \\
\hline Odds ratio & 2.52 & 2.32 \\
\hline
\end{tabular}

students in the highest quintile we estimate that the main source of income are the parents and relatives. We estimate that students from the lowest quintile rely mainly on income from parents and relatives $(59.8 \pm 2.3 \%$ of them) and on scholarships: $32.3 \pm 2.1 \%$, while the reference for the corresponding share of the sample is estimated to $11.3 \pm 1.4 \%$. Unfortunately, we cannot distinguish students whose household belong to the lowest income category from students who enjoy only limited financial autonomy from their parents and relatives. This is due to the construction of the questionnaire and it constitutes a limit of our analysis.

We used odds ratios to test the negative association between placement in income categories and appropriation of study grants. As failure in obtaining a study grant would result in paying tuition in a public or private university, we included in the analysis students from both types of universities. We note that the proportions in which students from lowest, middle and highest income quintiles appropriate study grants differs significantly from their level of representation in the overall student population, public and private universities included $(\chi 2(2)=30.114, \mathrm{p}<0.001$, $\mathrm{N}=987$, null hypothesis rejected). We calculated odds ratio between lowest and middle quintiles, and the highest one. The results are presented in the Table 9:

The odds ratio table indicates that students from the highest income quintile are considerably less likely to appropriate study grants than their less well off cohort fellows. On the other hand, they are considerably more likely to pay tuition fees. The odds ratio between lowest and highest income categories (2.52) can indicate low attractiveness of the study grants for the wealthiest students or the fact that tuition fees represent a significant obstacle for the students who declare the lowest income, or both. The odds ratio between middle and highest income quintiles (2.32) is in line with the former explanation. The comparison of the odds ratio provide additional evidence to accredit the thesis that incentives associated with the merit based distribution of study grants are weaker for wealthier students.

The null hypotheses are rejected for accommodation in student dormitories, in relation to all three "equity" variables, within the share of the sample which corresponds to public universities. The values of the standardised residuals exceed 2 in relation to parents' residence and parents' education, which indicates a significant discrepancy in the appropriation pattern. We calculated odds ratio between the least well off and the better off categories defined by the variables. The results are presented in the Table 10:

The relatively low value of the odds ratio corresponding to the lowest quintile can be explained by the fact that an important share of the students in this category live with their parents or with relatives $(44.0 \pm 2.3 \%)$, according to our estimates. For reference, the estimated proportion of students in public universities living with their parents or with relatives in the corresponding share of the sample amounts 
Table 10 Appropriation of accommodation facilities in student dormitories: odds ratio

\begin{tabular}{l|l|l|l|l}
\hline & Rural/Urban & $\begin{array}{l}\text { Lower/Higher } \\
\text { education }\end{array}$ & $\begin{array}{l}\text { Lowest/Highest } \\
\text { quintiles }\end{array}$ & $\begin{array}{l}\text { Middle/Highest } \\
\text { quintiles }\end{array}$ \\
\hline $\begin{array}{l}\text { Odds } \\
\text { ratio }\end{array}$ & 1.94 & 1.48 & 1.34 & 1.71 \\
\hline
\end{tabular}

$30.3 \pm 2.1 \% .{ }^{35}$ If we calculate the odds that a student lives in more comfortable facilities i.e. owning an apartment, or renting an apartment by oneself or with others, then the association is re-established. Students from the highest quintile stand 5.90 times more chances to live in more comfortable facilities than their counterparts from the other end of the income spectrum (quintile i), and 2.37 times more chances than middle income students (quintiles ii-iv). Overall, student dormitories stand more chances to be inhabited by students from the least well off categories within public universities, when they do not live with their parents or with their relatives.

\section{Conclusions}

Student subsidies are recognised to serve two functions: to incentivise achievement and to provide social support. We labelled subsidies as geared towards quality when merit-based logic is prevalent in the associated distributive pattern; following a similar logic, a distributive pattern which is prevalently sensitive to students' background was categorised as indicating an orientation towards equity.

We found that merit is the staple criterion based on which subsidies were distributed in the entire post-1989 period and were still distributed as of this writing. For study grants, distribution based on academic results constitutes the norm. Merit and needs are associated with different types of scholarships; the value and the proportion of the total budget allocated for each type of scholarship denote a net orientation towards quality. In the past two decades the attempts to change the status quo failed and the accepted incremental adjustments did not change the overall orientation. In the case of study grants, salient features of past arrangements indicate that the distribution pattern exhibits a considerable dose of path-dependence. The proposed revision to allow for the distribution of partial study grants was neutral to quality and equity, while allowing for more room of maneuver at the university level; yet it did not pass. The student loan alternative which imposed in its first version both quality and equity thresholds did not become effective. In the case of scholarships, the proposed revision was explicitly oriented towards ballancing quality and equity, and this was one of the main reasons it was discarded.

35 The estimates are highly significant: $\chi^{2}=47.507, \mathrm{p}<0.001, \mathrm{~N}=858, \mathrm{df}=8$. 
Over the past twenty years the pool of subsidies available to students has generally grown. However, the ratio between those who appropriated the subsidies and those who didn't, though they were eligible, fluctuated. The current provision of study grants and accommodation facilities reflects capacities from a past period of high enrolments, when efforts were made to increase capacities to cater for the unsatisfied demand. The issue of efficiency in resource utilisation becomes stringent in this context, especially if pressures on the public budget are to continue.

Are Romania's talents wisely spent? The current arrangements present major shortcomings in relation to equity in the first place. The results of our analysis indicate that the distribution of study grants, scholarships and accommodation facilities in student dormitories is generally neutral to students' family background, which implies a marginal contribution to the overcoming of the analyzed inequalities. The current situation represents an improvement as compared to the early 2000s, when subsidies supported the reproduction of the social structure within the universities, according to the conclusions of Vlăsceanu and Dima (2000), and Pasti (1998). This evolution was not the consequence of an intentional change of orientation - it is rather associated with the expansion of higher education and probably with the fact that many better off families choose to send their childrens for studies abroad. ${ }^{36}$

The evolutions discussed above are also important for the configuration of potential opponents to equity-oriented reforms within the student body. In the late nineties, the distribution of subsidies was concentrated towards a socio-economic elite, which, in theory, stood more chances to mobilise opposition than a heterogeneous and more numerous group, such as that of the beneficiaries of subsidies in 2011. An indication that a move towards equity may be accepted on the side of the students is represented by the fact that an important national federation of student organisations recently became supportive towards equity policies (ANOSR 2013).

Overall, we consider that the current context is more favourable to a shift of orientation towards a more balanced relation between equity and quality in the public policies regarding student subsidies than that of the late nineties. In terms of efficiency, a combination of merit and needs criteria could prove more rewarding from both the equity and quality perspectives, as current arrangements present major shortcomings in both respects.

Open Access This chapter is distributed under the terms of the Creative Commons Attribution Noncommercial License, which permits any noncommercial use, distribution, and reproduction in any medium, provided the original author(s) and source are credited.

\footnotetext{
36 The magnitude of this tendency cannot be properly assessed. The figures advanced - 22000,35 000 and 50000 for 2010, are estimates by various NGO's. See http://www.zf.ro/eveniment/catistudenti-romani-invata-in-strainatate-22-000-35-000-sau-50-000-6952029, accessed in October, 16th, 2013.
} 


\section{References}

Adevărul. (2010). Principiu universitar la Iaşi: taxe mai mari, avantaje mai puţine. Adevărul, 20 decembrie.

Agresti, A. (2007). An introduction to categorical data analysis. Vol. 423: Wiley-Interscience.

ANOSR. (2010). Studiu cu privire la statutul social al studentului din 2010. In Alianța Națională a Organizaţiilor Studenţești din România. http://www.avocatnet.ro/UserFiles/articleFiles/studiu_ anosr_cu_privire_la_statutul_social_al_studentului_din_romania_2010_09281150.pdf.

ANOSR. (2013). Politică privind dimensiunea socială a învățământului Superior. www.anosr.ro: Alianța Națională a Organizațiilor Studențești din România.

Berciu-Drăghicescu, A. (2004). Universitatea din București în primii 50 de ani de existenţă. In A. Berciu-Drăghicescu \& O. Bozgan (Eds.), O istorie a Universităţii Bucureşti, 1864-2004 (pp. 9-99). București: Editura Universităţii din București.

Berlescu, Dumitru. (1960). Universitatea din Iaşi de la 1860 până la 1918. In Universitatea "Al. I. Cuza" (Eds.), Contribuţii la istoria dezvoltării universităţii din Iaşi: 1860-1960 (pp. 82-245). Iași: București.

Bevc, Milena, \& Uršič, Sonja. (2008). Relations between funding, equity, and efficiency of higher education. Education Economics, 16(3), 229-244.

Bozgan, O. (2004). Avatarurile Universității din București în perioada regimului comunist. In A. Berciu-Drăghicescu \& O. Bozgan (Eds.), $O$ istorie a Universităţii din Bucureşti, (pp. 273-325). Editura Universității București.

Cabinet Decision 1402/2009. In HOT $\breve{A} \hat{A R E}$ nr. 1.402 din 18 noiembrie 2009 privind infiinţarea, organizarea şi funcţionarea Agenţiei de Credite şi Burse de Studii. MONITORUL OFICIAL nr. 821 din 30 noiembrie 2009

Cabinet Decision 558/1998. In Hotărârea nr. 558/1998 pentru modificarea anexelor nr. 1 şi 2 la Hotărârea Guvernului nr. 445/1997 privind stabilirea criteriilor generale de acordare a burselor şi a altor forme de sprijin material pentru elevii, studenţii şi cursanţii din invățământul de stat, cursuri de zi. Published in Monitorul Oficial, Partea I nr. 347 din 14.09.1998.

Cabinet Ordinance 105/1998. In ORDONANTA Nr. 105 din 27 August 1998 privind acordarea de credite bancare pentru studentii din invatamantul de stat. MONITORUL OFICIAL NR. 321 din 28 August 1998.

Cabinet Ordinance 5/2009. In Ordonanţa nr. 5/2009 privind înfiinţarea Agenţiei de Credite pentru Studenţii din Instituţiile de Învăţământ Superior de Stat şi Particular Acreditate. Monitorul Oficial, Partea I nr. 60 din 30.01.2009.

Cluj, Ziua de. (2013). "Eşti student și rămâi peste vară în Cluj, plătești transportul din banii tăi." Ziua de Cluj, 22 iulie.

CNFIS. (2011). Propunere privind estimarea cuantumului minim al bursei sociale. Consiliul Național pentru Finanţarea Învățământului Superior. Unpublished.

CNFIS. (2013). Raport public anual—2012: Starea finanțării învățământului superior și măsurile de optimizare ce se impun. Consiliul Național pentru Finanțarea Învăţământului Superior. http://www.cnfis.ro/wp-content/uploads/2013/04/Raport\%20CNFIS\%202012\%20-\%20Starea $\% 20$ finantarii\%20invatamantului\%20superior..pdf.

EACEA, Eurydice, Eurostat, and Eurostudent. (2012). The European higher education area in 2012: Bologna process implementation report. Brussels: Eurydice.

Explanatory Memorandum. (2009). In Notă de fundamentare la Ordonanţa Guvernului nr. 5/2009 privind înfiinţarea Agenţiei de Credite pentru Studenţii din Instituţiile de Învățământ Superior de Stat şi Particular Acreditate. http://www.gov.ro/upload/articles/104187/101-nf-finala.pdf.

Field, S., Kuczera, M., \& Pont, B. (2007). No more failures: Ten steps to equity in education. Paris: Organisation for Economic Co-operation and Development.

INS. (2013). TEMPO Online. https://statistici.insse.ro/shop/?page=tempo1\&lang=ro: Institutul Naţional de Statistică. 
Jongbloed, B., de Boer, H., Enders, J., \& File, J. (2010). Progress in higher education reform across Europe: Governance and funding reform. Twente: CHEPS.

Law 193/1999. In Legea nr. 193/1999 pentru aprobarea Ordonanței Guvernului nr. 105/1998 privind acordarea de credite bancare pentru studenții din învăţământul de stat. Monitorul Oficial, Partea I nr. 613 din 15.12.1999.

Law 1/2011. In Legea Educaţiei Naţionale.

Marginson, S. (2011). Equity, status and freedom: A note on higher education. Cambridge Journal of Education, 41(1), 23-36.

MECTS. (2012). Raport privind starea învăţământului superior din România 2011. Ministerul Educației, Cercetării, Tineretului și Sportului. http://nou2.ise.ro/wp-content/uploads/2012/08/ Raport_privind_starea_inv_superior_din_Romania.pdf.

MEN. (2013). Ordinul MEN nr. 3544/2013 - cadrul general de organizare si desfasurare a admiterii in ciclurile de studii universitare de licenta, de master si de doctorat pentru anul universitar 2013-2014. Ministerul Educației Naționale.

Miroiu, A. (2005). Finanțarea învățământului superior în România. Evaluare și propunere de politici. http://www.cadi.ro/index.php/vizualizare/articol/multimedia/164.

Miroiu, A., \& Vlăsceanu, L. (2012). Relating quality and funding: The Romanian Case. In A. Curaj, P. Scott, L. Vlasceanu \& L. Wilson (Eds.), European higher education at the crossroads: between the Bologna Process and national reforms (pp 791-807). Dordrecht: Springer.

Pasti, V. (1998). Infrastructura sistemului de învățământ. In A. Miroiu (Ed.), Învăţământul românesc azi. Studii de diagnoza. Iași: Polirom.

Păunescu, M., Vlăsceanu, L., \& Miroiu, A. (2011). Calitatea învățământului superior din România: o analiză instituţională a tendințelor actuale. Iași: Polirom.

Rados, L. (2010). Studenții universităţii (1860-1914). In G. Iacob \& A.-F. Platon (Eds.), Istoria Universităţii din Iaşi (pp. 177-229). Editura Universităţii "Alexandru Ioan Cuza" din Iaşi.

Salmi, J., \& Hauptman, A. M. (2006). Innovations in tertiary education financing: A comparative evaluation of allocation mechanisms. Education Working Paper Series, 4, 38324.

Salmi, J., Hâj, C. M., \& Alexe, D. (2014). Equity from an institutional perspective in the Romanian higher education system. In A. Curaj, L. Deca, E. Egron-Polak \& J. Salmi. (Eds.), Higher education reforms in Romania: Between the Bologna process and national challenges. Dordrecht: Springer.

UTCN. 2012. Regulament privind criteriile de ierarhizare anuală a studenților pe locurile bugetate. http://www.utcluj.ro/media/documents/2013/2012_Regulament_criterii_ierarhizare_pe_locuri_ bugetate.pdf: Universitatea Tehnică din Cluj-Napoca.

Vese, V. (2012). Universitatea "Babeș-Bolyai" în perioada regimului comunist, 1959-1989. In I.-A. Pop, D. Radosav, I. V. Costea \& O. Ghitta (Eds.), Istoria Universităţii "BabeşBolyai"'(pp. 261-298). Cluj-Napoca: Mega.

Vîiu, G., \& Miroiu, A. (2014). The quest for quality in higher education: Is there any place left for equity and access? In A. Curaj, L. Deca, E. Egron-Polak \& J. Salmi (Eds.), Higher education reforms in Romania: Between the Bologna process and national challenges. Dordrecht: Springer.

Vlăsceanu, L., \& Dima, A.-M. (2000). Întâlnire cu studenţiii. București: Paideia.

Vlăsceanu, L., Miroiu, A., Păunescu, M., \& Hâncean, M.-G. (2011). Barometrul Calității 2010. Starea calităţii în învăţământul superior din România. Brașov: Editura Universităţii Transilvania din Braşov.

Voicu, B. (2007). Cine sunt studenţii de astăzi. In M. Comșa, Tufiș, C.D. \& Voicu, B. (Eds.), Sistemul universitar românesc: Opiniile cadrelor didactice şi ale studenţilor (pp. 24-26). București: AFIR.

Voicu, B., \& Rusu, R. (2011). Resursele umane în universități. In M. Păunescu, L. Vlăsceanu, \& A. Miroiu (Eds.), Calitatea învăţământului superior din România: o analiză instituţională a tendinţelor actuale (pp. 142-156). Iași: Polirom.

Voicu, B., \& Vasile, M. (2010). Rural-urban inequalities and expansion of tertiary education in Romania. Journal of Social Research \& Policy, 1(1), 5-24. 
World Bank. (1996). Staff appraisal report. edited by Romania. Reform of higher education and research project. http://www-wds.worldbank.org/external/default/WDSContentServer/WDSP/ IB/1996/08/26/000009265_3961019222444/Rendered/PDF/multi0page.pdf.

World Bank. (2003). Implementation completion and results report. In Romania. Reform of higher education and research project. http://www-wds.worldbank.org/external/default/WDSContent Server/WDSP/IB/2003/04/05/000094946_03032104003173/Rendered/PDF/multi0page.pdf. 